\title{
PRZEBIEG SYMULACJI KOMPUTEROWEJ PROCESU OCZYSZCZANIA SCIEKÓW KOMUNALNYCH W REAKTORZE OSADU CZYNNEGO
}

\begin{abstract}
Celem badań było ustalenie wpływu ilości i zakresu parametrów jakości ścieków surowych na wiarygodność wyników symulacji, co umożliwiłoby ustalenie optymalnej częstotliwości ich monitoringu, niezbędnego do pozyskiwania danych do modelowania w programach ASM. W artykule przedstawiono metodykę prowadzenia symulacji komputerowej procesu oczyszczania ścieków komunalnych w reaktorach biologicznych z osadem czynnym. Zaprezentowano sposób przygotowania i przetwarzania danych wejściowych do modelu oraz sposoby oceny i weryfikacji wyników symulacji za pomocą testów statystycznych. Modelowanie było wykonane w programie BioWin na przykładzie oczyszczalni ścieków komunalnych „Kujawy” w Krakowie. W oparciu o wstępne wyniki niniejszych badań można wnioskować, że w celu uzyskania wiarygodnych wyników symulacji pracy bioreaktora w modelu ASM niezbędne jest prowadzenie monitoringu podstawowych paramentów jakości ścieków online.
\end{abstract}

Słowa kluczowe: metoda osadu czynnego, monitoring ścieków, symulacja komputerowa, program BioWin, statystyka matematyczna

\section{Wstęp}

Oczyszczalnie ścieków należy rozpatrywać jako skomplikowany system technogeniczny, w skład którego wchodzi duża liczba rozmaitych procesów technologicznych. Modelowanie matematyczne, coraz bardziej powszechnie stosowane na etapie projektowania, modernizacji i eksploatacji oczyszczalni ścieków, pozwala zwiększyć jakość rozwiązania projektowego oraz zoptymalizować procesy transportu ścieków, mechaniczne, fizyko-chemiczne i biologiczne procesy oczyszczania, oraz prognozować ich oddziaływanie na odbiornik.

\footnotetext{
${ }^{1}$ Autor do korespondencji / corresponding author: Zbigniew Kowalewski, AGH Akademia Górniczo-Hutnicza, 30-059 Kraków, al. Mickiewicza 30a, 1261752 14, kowalew@agh.edu.pl

2 Elena Neverova-Dziopak, AGH Akademia Górniczo-Hutnicza, 30-059 Kraków, al. Mickiewicza 30a, 1261740 06, elenad@agh.edu.pl
} 
Służą temu odpowiednie symulacyjne i prognostyczne modele matematyczne [9].

BioWin jest specjalistycznym programem komputerowym kanadyjskiej firmy EnviroSim Associates Ltd. służącym do modelowania i symulacji wszelkiego rodzaju procesów oczyszczania ścieków, w tym m.in. biologicznego usuwania związków organicznych, nitryfikacji, denitryfikacji, chemicznego i biologicznego usuwania fosforu, procesów w układzie reaktorów SBR, reaktorów membranowych, rowów cyrkulacyjnych, tlenowej i beztlenowej fermentacji osadów, procesów separacji i wielu innych. W niniejsze pracy do modelowania procesów przebiegających $\mathrm{w}$ reaktorze biologicznym wykorzystany został program BioWin2 w wersji 2.2. Program ma zaimplementowane trzy modele osadu czynnego z grupy ASM (Activated Sludge Model): ASM1, ASM2d i ASM3. Dodatkowo zawiera on model nitryfikacji i przekształcania osadów. Model ASM1 to pierwszy z rodziny modeli stworzonych w 1987 roku na potrzeby International Association of Water Quality (obecnie IWA - International Water Association). ASM1 został stworzony do opisu procesów biologicznych służących do redukcji wartości ChZT oraz procesów nitryfikacji-denitryfikacji w ściekach komunalnych. Próby zastosowania go do modelowania oczyszczania ścieków przemysłowych najczęściej dają słabe rezultaty. Model jest oparty na 13 równaniach [6]. Rozwinięciem modelu ASM1 o biologiczną defosfatację był model ASM2 oraz ASM2d który uwzględnia aktywność mikroorganizmów akumulujących związki fosforu (PAO). Model ASM2 wykorzystuje 19 równań, natomiast model ASM2d - 21 [7]. Model ASM3 powstał w 2000 roku i stanowi rozwinięcie modelu ASM1. Podobnie jak i poprzedni, składa się z 16 równań i nie obejmuje procesów związanych z transformacją fosforu. Jest to jednak celowy zabieg autorów modelu, gdyż według nich ASM3 ma stanowić swoisty „szkielet" do budowania na nim kolejnych modeli [2]. Podstawowym ograniczeniem modeli z rodziny ASM jest wcześniej wspomniana ograniczona możliwość zastosowania do symulacji procesów oczyszczania ścieków przemysłowych, chociaż niektórzy autorzy proponują zastosowanie tego modelu do ścieków miejskich, komunalno-przemysłowych [8] lub pochodzących z niektórych gałęzi przemysłu, takich jak np. przemysł spożywczy lub papierniczy [3, 10].

\section{Symulacja pracy reaktorów biologicznych z osadem czynnym}

Modelowanie procesów biologicznego oczyszczania ścieków zostało przeprowadzone dla oczyszczalni ścieków komunalnych „Kujawy” zlokalizowanej w Krakowie. Oczyszczalnia obsługuje 250 tys. mieszkańców Nowej Huty i okolic. Jest to mechaniczno-biologiczna oczyszczalnia ze wzmożonym usuwaniem biogenów opartym na technologii osadu czynnego, wspomaganym chemicznym strącaniem fosforu. Odbiornikiem ścieków oczyszczonych jest rzeka Wisła. Ilość odprowadzanych ścieków oczyszczonych zgodnie z pozwoleniem wodno-prawnym nie może przekroczyć w okresie bezdeszczowym średnio $80000 \mathrm{~m}^{3} / \mathrm{d}$ 
i maksymalnie $100000 \mathrm{~m}^{3} / \mathrm{d}$ i $4660 \mathrm{~m}^{3} / \mathrm{h}$. W okresie deszczowym i w czasie roztopów dopuszcza się odprowadzanie $9320 \mathrm{~m}^{3} / \mathrm{h}$.

Mechaniczna część oczyszczalni składa się z: żwirownika, krat rzadkich, piaskownika z napowietrzaniem, krat gęstych oraz osadników wstępnych. Część biologiczną stanowią trzyfazowe reaktory z wydzielonymi sekcjami: beztlenową, niedotlenioną i tlenową, $\mathrm{z}$ recyrkulacją wewnętrzną. Sumarycznie każdy reaktor składa się z 9 komór o głębokości $4,7 \mathrm{~m}$ i łącznej objętości $16010 \mathrm{~m}^{3}$. W linii recyrkulacji zewnętrznej dodatkowo stosowana jest komora predenitryfikacji o głębokości 3,36 m i objętości $620 \mathrm{~m}^{3}$. Komory beztlenowe i fakultatywne wyposażone są w mieszadła wolnoobrotowe, a komory tlenowe - dodatkowo w ruszt napowietrzający. Obecnie funkcjonują cztery linie technologiczne bioreaktorów, każda zakończona dwoma osadnikami wtórnymi. Są to osadniki radialne o średnicy 42 metrów i głębokości czynnej $3 \mathrm{~m}$, wyposażone w zgarniacze [5]. Schemat technologiczny oczyszczalni oraz bioreaktora przedstawiają rysunki 1 oraz 2.

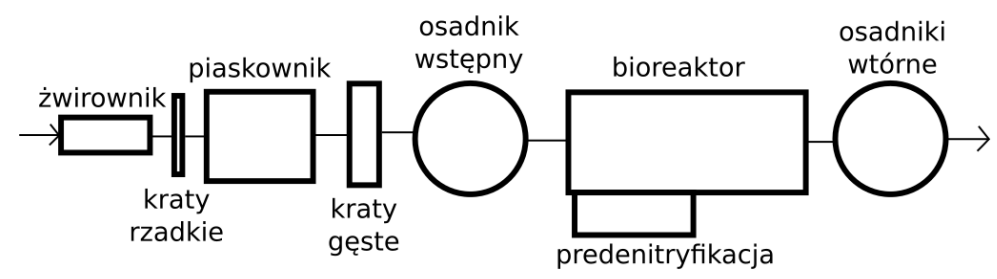

Rys. 1. Schemat technologiczny oczyszczalni ścieków „Kujawy” w Krakowie

Fig. 1. Technological scheme of wastewater treatment plant „Kujawy” in Cracow

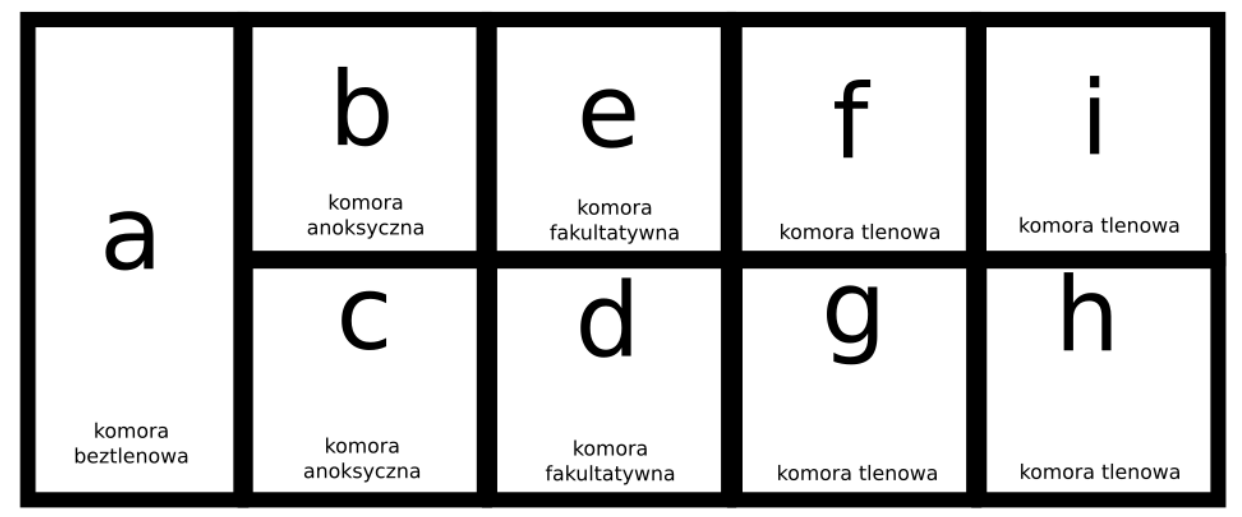

Rys. 2. Schemat bioreaktora $\mathrm{z}$ wydzielonymi komorami

Fig. 2. Scheme of bioreactor with separated chambers 
Do modelowania wykorzystano wartości podstawowych parametrów jakości ścieków oznaczanych przez laboratorium oczyszczalni w roku 2013. Laboratorium prowadzi monitoring regularnie w odstępach dwutygodniowych. Badaniu podlega 27 parametrów jakości ścieków w tym: pH, BZT i ChZT, formy azotu i fosforu oraz temperatura ścieków w bioreaktorze. Do wykonania symulacji procesu oczyszczania w programie BioWin wymagane są następujące dane: data badania, natężenie przepływu oraz wartości takich parametrów jak: ChZT, azot Kjeldahla, fosfor całkowity, azot azotanowy, pH, zasadowość, zawiesina, wapń, magnez, tlen rozpuszczony, temperatura ścieków w bioreaktorach. Minimalny zakres parametrów niezbędnych do uruchomienia modelu obejmuje: ChZT, azot Kjeldahla i fosfor ogólny. Pozostałe parametry można pozostawić jako stałe lub będą one domyślnie przyjęte przez program. Baza danych stosowanych w badaniach składała się z 21 zestawów parametrów. Każdy zestaw powstaje w oparciu o wyniki regularnego dwutygodniowego monitoringu i składa się $\mathrm{z}$ takich parametrów jak: pH, ChZT, zawiesina, azot Kjeldahla, azot azotanowy i fosfor ogólny. Te parametry stanowiły podstawę do realizacji procesu modelowania. Parametrem dodatkowym była temperatura zarejestrowana w bioreaktorze. Celem badań było sprawdzenie jak zachowa się model symulacyjny procesu oczyszczania ścieków metodą osadu czynnego w sytuacji braku danych lub niepełnego zestawu danych. Na potrzeby badań stworzono osiem symulacji, każdą z innym zakresem danych wejściowych. Zmieniono interwał między poborem próbek ścieków z dwutygodniowego na dobowy, co umożliwiło przeprowadzenie symulacji stanu dynamicznego. Takie rozwiązanie umożliwia przeprowadzenie symulacji dynamicznej. Zwiększenie częstotliwości wprowadzania danych nie powodowało różnic w obliczeniach, ale zwiększało czas obliczeń. Z kolei zastosowanie interwału godzinnego spowodowało niestabilność symulacji. Dane użyte do kompletowania poszczególnych zestawów na potrzeby symulacji są przedstawione w tabeli 1.

Symulacje różniły się ilością danych (12 lub 21 zestawów danych, każdy po 6 parametrów: $\mathrm{pH}$, ChZT, azot Kjeldahla, azot azotanowy, fosfor ogólny, zawiesina), temperaturą (stała dla całości symulacji lub zmienna). Dodatkowo wyróżniono dwa zakresy danych: niepełny, w którym wartość pH i zawiesiny były stałe i wynosiły odpowiednio 7,3 i $210 \mathrm{mg} / \mathrm{l}$ oraz zmienne). Symulacje od $\mathrm{nr} 1$ do $\mathrm{nr} 4$ były realizowane dla okresu $36 \mathrm{dni}$, natomiast symulacja z pełnym zestawem danych (symulacje od $\mathrm{nr} 5$ do $\mathrm{nr} 8$ ) - dla okresu 54 dni. Okres ten był dobrany eksperymentalnie w kolejnych uruchomieniach modelu i miał na celu umożliwić podgląd całości.

Do dalszych obliczeń w programie BioWin2 została skonstruowana linia technologiczna oczyszczalni ścieków „Kujawy”, która jest przedstawiona na rysunku 3. Zakłada ona pewne uproszczenia w schemacie, nie wpływające na samą symulację. Uproszczenia polegają na połączeniu komór reaktora spełniających te same funkcje w jedną komorę. Finalnie wyodrębniono komorę beztlenową, fakultatywną i tlenową oraz komorę predenitryfikacji. Dodatkowo dwa 
osadniki wtórne połączono w jeden. Recyrkulacja wewnętrzna wynosiła 160\%, recyrkulacja zewnętrzna - 60\%, odpływ osadu nadmiernego wynosił 5\% całkowitego początkowego strumienia šcieków.

Tabela 1. Dane stosowane w symulacjach

Table 1. Data used in simulation

\begin{tabular}{|c|c|c|c|c|}
\hline Nr symulacji & $\begin{array}{c}\text { Liczba } \\
\text { zestawów } \\
\text { danych }\end{array}$ & $\begin{array}{c}\text { Temperatura } \\
{ }^{\mathbf{0}} \mathbf{C}\end{array}$ & $\begin{array}{c}\text { Zakres } \\
\text { danych }\end{array}$ & $\begin{array}{c}\text { Zadany okres } \\
\text { symulacji }\end{array}$ \\
\hline 1 & 12 & 19,13 & niepełne & $36 \mathrm{dni}$ \\
\hline 2 & 12 & $\mathbf{1 1 , 9 - 2 6 , 8}$ & niepełne & $36 \mathrm{dni}$ \\
\hline 3 & 12 & 19,13 & pełne & $36 \mathrm{dni}$ \\
\hline 4 & 12 & $\mathbf{1 1 , 9 - 2 6 , 8}$ & pełne & $36 \mathrm{dni}$ \\
\hline 5 & 21 & 17,45 & niepełne & $54 \mathrm{dni}$ \\
\hline 6 & 21 & $\mathbf{1 1 , 9 - 2 6 , 8}$ & niepełne & $54 \mathrm{dni}$ \\
\hline 7 & 21 & 17,45 & pełne & $54 \mathrm{dni}$ \\
\hline 8 & 21 & $\mathbf{1 1 , 9 - 2 6 , 8}$ & pełne & $54 \mathrm{dni}$ \\
\hline
\end{tabular}

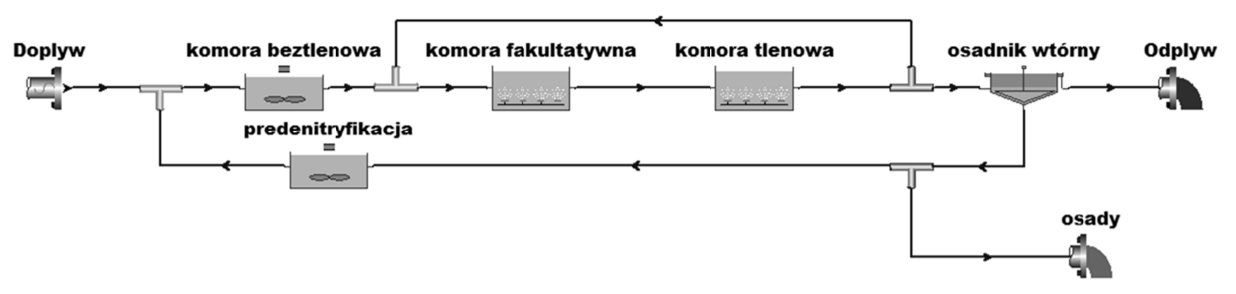

Rys. 3. Schemat oczyszczalni „Kujawy” w programie BioWin

Fig. 3. „Kujawy” WWTP diagram created in BioWin software

Dalszym etapem badań była weryfikacja wyników symulacji procesu biologicznego oczyszczania ścieków na podstawie porównania wartości parametrów rzeczywistych z wartościami obliczonymi przez model. Dynamikę zmian wartości symulowanych i rzeczywistych w czasie przedstawiono na rysunkach 4 i 5 . 

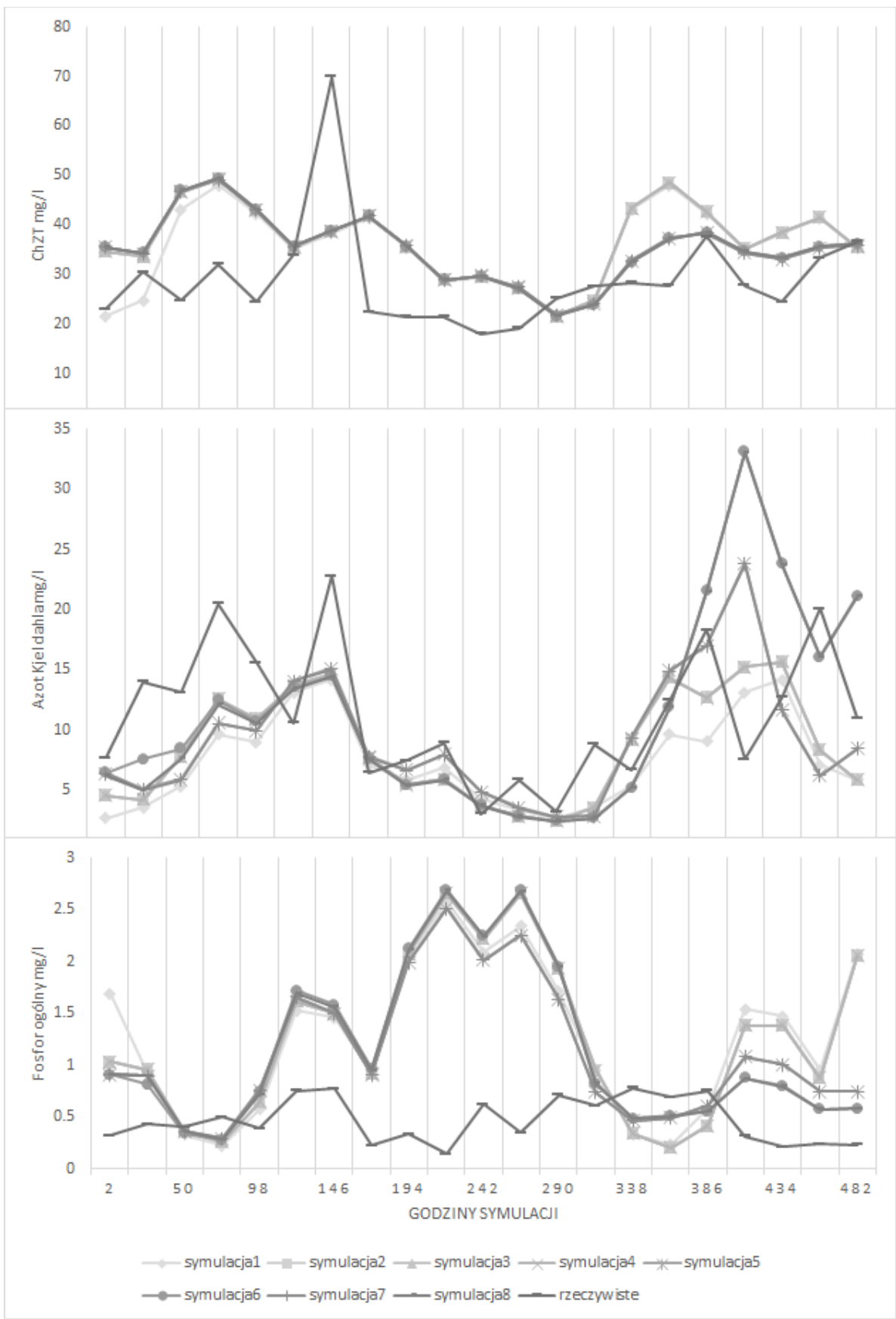

Rys. 4. Wyniki symulacji wartości ChZT, azotu Kjeldahla i fosforu ogólnego na tle wartości rzeczywistych

Fig. 4. Results of COD, TKN and Total phosphorus values simulation against real values 


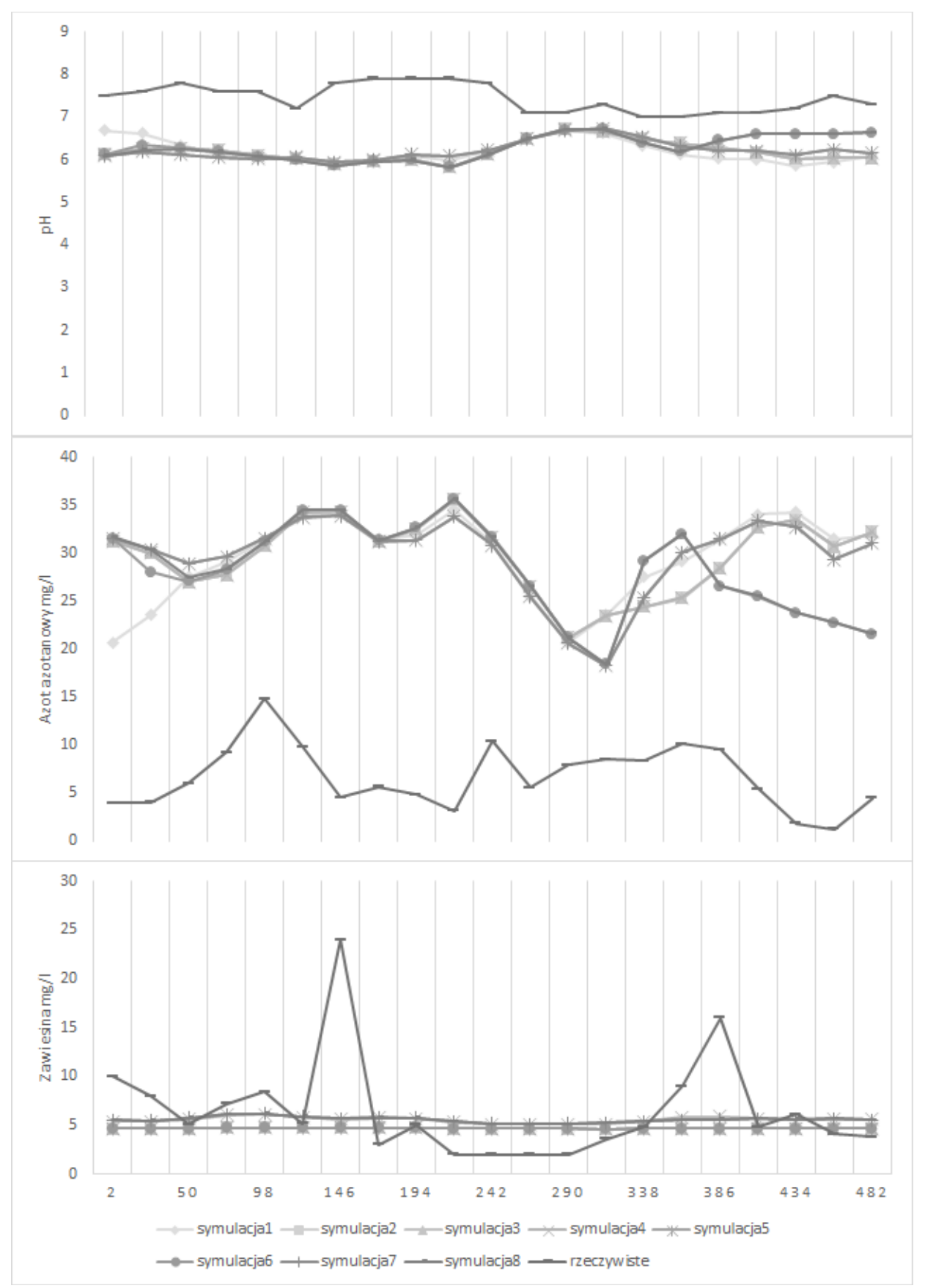

Rys. 5. Wyniki symulacji wartości pH, azotu azotanowego i zawiesiny wraz na tle wartości rzeczywistych

Fig. 5. Results of $\mathrm{pH}, \mathrm{N}-\mathrm{NO}_{3}$ and TSS values simulation against real values 
Najbardziej zbliżone do wartości rzeczywistych przebiegi wykazuje wartość azotu Kjeldahla oraz wartosć ChZT. Wykres dla azotu azotanowego charakteryzuje się podobnym przebiegiem, lecz wszystkie jego wartości symulacyjne sa większe od wartosci rzeczywistych. Modelowe wyniki dla zawiesiny są bardzo regularne, co daje zbliżone wyniki do rzeczywistych gdy zawiesina nie ma dynamicznych zmian, natomiast symulacje nie uwzględniają nagłych zmian stężeń rzeczywistych. Wartosć symulowana fosforu ogólnego jest większa od wartości rzeczywistych w każdym z modelowanych przypadków. Model zbyt agresywnie reagował na podwyższone stężenia fosforu ogólnego w ściekach surowych. Dla wartości niższych model dawał rezultaty podobne do rzeczywistych. Przebieg modelowych linii dla $\mathrm{pH}$ jest podobny do rzeczywistych, jednak wszytkie symulacje zaniżają rzeczywistą wartość pH.

\section{Analiza wyników symulacji na podstawie testów statystycznych}

Do analizy wyników symulacji zastosowano: analizę wariancji w celu sprawdzenia czy wyniki uzyskane w symulacją są statystycznie istotne oraz współczynnik korelacji Pearsona (r) do sprawdzenia zbieżności symulowanych parametrów z danymi rzeczywistymi. Analizy wykonano w programie Statistica 12.5. Dodatkowo zastosowano statystyki KGE (Kling-Gupta efficiency), ME (Mean Error), PBIAS (Percent Bias) wykonane $\mathrm{z}$ programie $\mathrm{R}$ wersja 3.2.2 64-bit przy pomocy pakietu hydroGOF $w$ wersji 0.3-8 [11]. Wszystkie obliczenia wykonywane były z poziomem istotności 0,05 . W celu sprawdzenia normalności rozkładu oraz homogeniczności wariancji zastosowano test Shapiro-Wilka oraz test Lavena.

\section{ANOVA}

Analiza wariancji i wartości współczynnika korelacji wykonana dla poszczególnych symulacji wykazywała podobieństwa między nimi.

W przypadku azotu azotanowego wyniki symulacji znacząco różnią się od wartości rzeczywistych. Podobnie jest w wypadku $\mathrm{pH}$ i fosforu ogólnego. W przypadku zawiesiny zbieżność w wynikach uzyskano dla symulacji $\mathrm{nr} 4,7$ i 8 z kompletem danych. Wartości symulowane i rzeczywiste dla azotu Kjeldahla oraz ChZT nie wykazują różnic, aczkolwiek zgodność symulowanych wyników ChZT z rzeczywistymi jest nieco niższa niż w przypadku azotu Kjeldahla (rys. 6).

Dla uszczegółowienia wyników testu ANOVA przeprowadzono test post-hoc HSD Tukeya, którego wyniki prezentuje tabela 2. 
Analiza wariancji

Pionowe słupki oznaczają 0.95 przedziały ufności

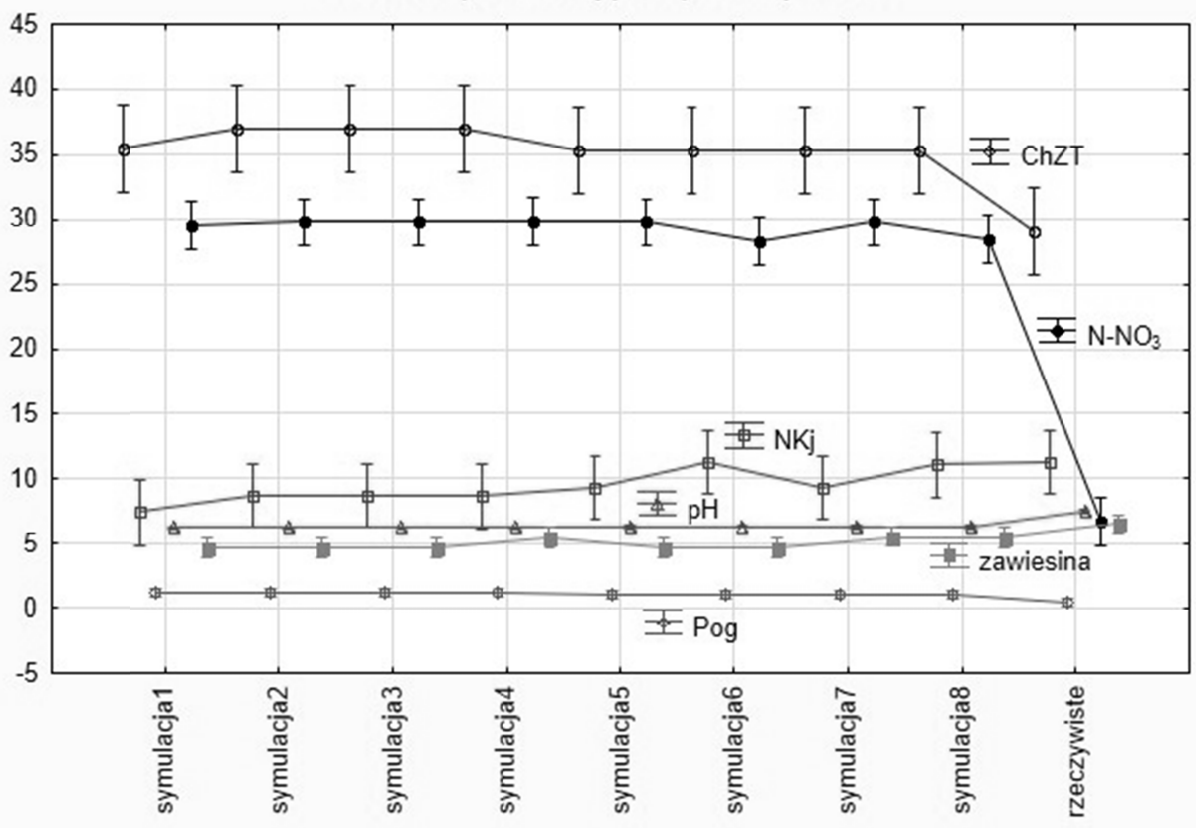

Rys. 6. Wyniki analizy wariancji

Fig. 6. ANOVA results

Tabela 2. Wyniki testu HSD Tukeya (x oznacza brak różnic pomiędzy symulacjami a wartościami rzeczywistymi)

Table 2. HSD Tukey test results (x means no significant differences between simulations and real values)

\begin{tabular}{|c|c|c|c|c|c|c|}
\hline Symulacja & ChZT & NKj & Pog & pH & N-NO & Zawiesina \\
\hline Symulacja1 & $\mathrm{x}$ & $\mathrm{x}$ & & & & \\
\hline Symulacja2 & & $\mathrm{x}$ & & & & \\
\hline Symulacja3 & & $\mathrm{x}$ & & & & \\
\hline Symulacja4 & & $\mathrm{x}$ & & & & $\mathrm{x}$ \\
\hline Symulacja5 & $\mathrm{x}$ & $\mathrm{x}$ & $\mathrm{x}$ & & & \\
\hline Symulacja6 & $\mathrm{x}$ & $\mathrm{x}$ & & & & \\
\hline Symulacja7 & $\mathrm{x}$ & $\mathrm{x}$ & $\mathrm{x}$ & & & $\mathrm{x}$ \\
\hline Symulacja8 & $\mathrm{x}$ & $\mathrm{x}$ & & & & $\mathrm{x}$ \\
\hline
\end{tabular}




\section{Wspótczynnik korelacji Pearsona}

Współczynniki korelacji pomiędzy wynikami symulacji (r) są wysokie i przekraczają 0.9. Poziom korelacji z wartościami rzeczywistymi prezentuje tabela 3. Wyniki dla ChZT są na niskim poziomie jednak jednakowe dla wszystkich symulacji, najwyższe korelacje uzyskano dla azotu Kjeldahla w przypadku symulacji dla krótszego okresu z niepełnym zestawem danych. Wyniki dla zawiesiny są na poziomie $0,3-0,4$, jedynie dla symulacji z pełnym zakresem danych uzyskano znacznie lepsze wyniki na poziomie 0,51 . Wyniki dla pozostałych parametrów nie są istotne statystycznie.

Tabela 3. Współczynniki korelacji dla symulacji

Table 3. Correlation coefficients for simulations

\begin{tabular}{|c|c|c|c|c|c|c|c|}
\hline Symulacja & Statystyka & ChZT & NKj & Pog & pH & N-NO $_{3}$ & Zawiesina \\
\hline Symulacja1 & $\mathrm{r}$ & 0,24 & 0,51 & $-0,37$ & $-0,22$ & 0,25 & 0,18 \\
\hline Symulacja2 & $\mathrm{r}$ & 0,23 & 0,56 & $-0,3$ & $-0,61$ & 0,19 & 0,35 \\
\hline Symulacja3 & $\mathrm{r}$ & 0,23 & 0,56 & $-0,3$ & $-0,61$ & 0,19 & 0,35 \\
\hline Symulacja4 & $\mathrm{r}$ & 0,23 & 0,56 & $-0,3$ & $-0,61$ & 0,19 & 0,48 \\
\hline Symulacja5 & $\mathrm{r}$ & 0,24 & 0,35 & $-0,13$ & $-0,58$ & 0,15 & 0,37 \\
\hline Symulacja6 & $\mathrm{r}$ & 0,24 & 0,41 & $-0,05$ & $-0,66$ & $-0,21$ & 0,37 \\
\hline Symulacja7 & $\mathrm{r}$ & 0,24 & 0,35 & $-0,13$ & $-0,58$ & 0,15 & 0,51 \\
\hline Symulacja8 & $\mathrm{r}$ & 0,24 & 0,39 & $-0,06$ & $-0,68$ & $-0,21$ & 0,51 \\
\hline
\end{tabular}

ME, KGE i PBIAS

Statystyka ME oznacza średnie odchylenie od wartości rzeczywistych. Im mniejsza wartość bezwzględna, tym lepsze dopasowanie. Wyniki oceny modeli za pomocą ME przedstawia tabela 4. Najlepsze wyniki uzyskano dla fosforu, aczkolwiek pozostałe parametry również nie wykazują nadmiernych rozbieżności.

Statystyka KGE powstała jako rozwinięcie metody Nash-Sutcliffe (NSE). Łączy w sobie metody NSE, r Pearsona i ME. KGE pokazuje jak bardzo iloraz wartości symulowane/rzeczywiste różni się od ilorazu 1:1 [1, 11]. Według tej statystyki najkorzystniej zasymulowane są dane dla ChZT i azotu Kjeldahla. Pozostałe symulowane parametry nie osiągają statystycznej zgodności z rzeczywistymi wartościami. Wyniki analizy KGE przedstawione są w tabeli 5. 
Tabela 4. Średni błąd symulacji

Table 4. Simulation mean error ME

\begin{tabular}{|l|c|c|c|c|c|c|c|}
\hline Symulacja & Statystyka & ChZT & NKj & Pog & pH & N-NO $_{3}$ & Zawiesina \\
\hline Symulacja1 & ME & 6,43 & $-3,88$ & 0,8 & $-1,25$ & 14,05 & $-5,62$ \\
\hline Symulacja2 & ME & 7,91 & $-2,64$ & 0,79 & $-1,24$ & 14,33 & $-5,6$ \\
\hline Symulacja3 & ME & 7,91 & $-2,64$ & 0,79 & $-1,24$ & 14,33 & $-5,6$ \\
\hline Symulacja4 & ME & 7,91 & $-2,65$ & 0,79 & $-1,24$ & 14,33 & $-4,73$ \\
\hline Symulacja5 & ME & 6,18 & -2 & 0,66 & $-1,22$ & 14,31 & $-5,6$ \\
\hline Symulacja6 & ME & 6,2 & 0 & 0,69 & $-1,15$ & 12,85 & $-5,6$ \\
\hline Symulacja7 & ME & 6,18 & $-2,01$ & 0,66 & $-1,22$ & 14,32 & $-4,72$ \\
\hline Symulacja8 & ME & 6,19 & $-0,22$ & 0,69 & $-1,16$ & 13 & $-4,72$ \\
\hline
\end{tabular}

Tabela 5. Wartość statystyki KGE dla symulacji

Table 5. KGE values for simulations

\begin{tabular}{|l|c|c|c|c|c|c|c|}
\hline Symulacja & Statystyka & ChZT & NKj & Pog & pH & N-NO $_{\mathbf{3}}$ & Zawiesina \\
\hline Symulacja1 & KGE & 0,18 & 0,32 & $-2,23$ & $-0,24$ & $-0,48$ & $-0,4$ \\
\hline Symulacja2 & KGE & 0,13 & 0,46 & $-2,37$ & $-0,64$ & $-0,52$ & $-0,31$ \\
\hline Symulacja3 & KGE & 0,13 & 0,46 & $-2,37$ & $-0,64$ & $-0,52$ & $-0,31$ \\
\hline Symulacja4 & KGE & 0,13 & 0,46 & $-2,37$ & $-0,64$ & $-0,52$ & $-0,2$ \\
\hline Symulacja5 & KGE & 0,12 & 0,33 & $-1,7$ & $-0,63$ & $-0,54$ & $-0,3$ \\
\hline Symulacja6 & KGE & 0,13 & 0,27 & $-2,15$ & $-0,67$ & $-0,71$ & $-0,3$ \\
\hline Symulacja7 & KGE & 0,12 & 0,32 & $-1,7$ & $-0,63$ & $-0,54$ & $-0,19$ \\
\hline Symulacja8 & KGE & 0,13 & 0,24 & $-2,12$ & $-0,69$ & $-0,72$ & $-0,19$ \\
\hline
\end{tabular}

Ostatnim sposobem, służącym do oceny rezultatów symulacji, był PBIAS. Parametr ten w sposób procentowy pokazuje tendencję średnią symulowanych parametrów do przyjmowania wartości większych lub mniejszych od rzeczywistych [4]. Podobnie jak dla statystyk KGE i ME, najlepsze rezultaty uzyskano dla ChZT, azotu Kjeldahla oraz dla pH. Zawiesina jest niedoszacowana, natomiast fosfor jest tak, jak w pozostałych przypadkach znacznie przeszacowany (tab. 6). 
Tabela 6. Wartość statystyki PBIAS dla symulacji

Table 6. Simulation PBIAS values

\begin{tabular}{|l|c|c|c|c|c|c|c|}
\hline Symulacja & Statystyka & ChZT & NKj & Pog & pH & N-NO $_{3}$ & Zawiesina \\
\hline Symulacja1 & PBIAS & 22,1 & $-34,3$ & 170,7 & $-16,8$ & 91 & $-54,7$ \\
\hline Symulacja2 & PBIAS & 27,2 & $-23,4$ & 169,5 & $-16,7$ & 92,8 & $-54,5$ \\
\hline Symulacja3 & PBIAS & 27,2 & $-23,4$ & 169,5 & $-16,7$ & 92,8 & $-54,5$ \\
\hline Symulacja4 & PBIAS & 27,2 & $-23,5$ & 169,5 & $-16,7$ & 92,9 & -46 \\
\hline Symulacja5 & PBIAS & 21,3 & $-17,7$ & 140,4 & $-16,4$ & 92,8 & $-54,5$ \\
\hline Symulacja6 & PBIAS & 21,3 & 0 & 147 & $-15,4$ & 83,3 & $-54,5$ \\
\hline Symulacja7 & PBIAS & 21,3 & $-17,8$ & 140,4 & $-16,4$ & 92,8 & $-45,9$ \\
\hline Symulacja8 & PBIAS & 21,3 & $-1,9$ & 146,9 & $-15,6$ & 84,2 & $-45,9$ \\
\hline
\end{tabular}

\section{Podsumowanie}

W artykule przestawiono badania nad wpływem sposobu przygotowania oraz zakresu i kompletności danych wejściowych na wyniki symulacji komputerowej procesu oczyszczania ścieków komunalnych metodą osadu czynnego, zrealizowane w programie BioWin. Symulację przeprowadzono w wykorzystaniem wskaźników jakości ścieków komunalnych oczyszczalni „Kujawy” w Krakowie.

Rzeczywiste wartości parametrów jakości ścieków pochodzą z monitoringu prowadzonego przez oczyszczalnie, realizowanego z częstotliwością co $14 \mathrm{dni}$, natomiast na potrzeby modelu przekształcono je na częstotliwość jednodniową, co umożliwiło wykonanie symulacji dynamicznej (upływ czasu jako warunek brzegowy).

Utworzono 8 zestawów danych wejściowych do symulacji i monitorowano zmiany 6 parametrów: ChZT, pH, zawiesiny, azotu Kjeldahla i azotu azotanowego oraz fosforu ogólnego. Oceny wyników symulacji dokonano w sposób wizualny, a także przy pomocy analizy wariancji i testu HSD Tukeya oraz metod statystycznych takich jak: współczynnik korelacji Pearsona, błąd średni (ME), KGE i PBIAS.

Najlepsze rezultaty symulacji zostały uzyskane dla azotu Kjeldahla. Wyniki symulacji dla tego parametru są istotne statystycznie i zgodne z danymi rzeczywistymi. Nieco słabszy efekt uzyskano dla ChZT. Niemiej jednak okazało się, że te dwa parametry najłatwiej i najszybciej poddają się modelowaniu. Testy statystyczne dla tych dwóch parametrów nie wykazały istotnych różnic między poszczególnymi symulacjami. Symulacje oparte na pełnych zestawach danych wykazywały lepsze zbieżności z danymi rzeczywistymi, jednak nie na tyle, aby można było mówić o istotnych różnicach w wynikach symulacji. 
W przypadku symulacji zawartości zawiesiny najlepsze rezultaty uzyskano dla symulacji $\mathrm{nr} 8 \mathrm{z}$ pełnym zestawem parametrów.

Wartości symulowane i rzeczywiste azotu azotanowego charakteryzują się podobną dynamiką, lecz wartości uzyskane w wyniku symulacji są zbyt wysokie w porównaniu z rzeczywistymi. W przypadku symulacji wartości $\mathrm{pH}$ : przy podobnej dynamice, parametry symulowane miały niższe wartości,

Najsłabsze rezultaty uzyskano przy symulacji zawartości fosforu ogólnego. Model nie potrafił dostosować się dynamicznych zmian wartości rzeczywistych. Najlepsze rezultaty uzyskano dla symulacji $\mathrm{nr} 8$, opartej na pełnym zestawie danych wejściowych, czyli na 147 wartościach następujących parametrów: ChZT, pH, zawiesina, azot Kjeldahla, azot azotanowy, fosfor ogólny i temperatura w bioreaktorze. Dobre wyniki uzyskano dla symulacji nr 4, opartej na 80 wartościach wymienionych parametrów.

Wyniki uzyskane na podstawie sformułowanych modeli symulacyjnych zapewniają poziom wiarygodności, uwarunkowany dokładnością i zakresem dostępnej informacji wyjściowej.

Podsumowując wyniki przeprowadzonych symulacji parametrów jakości ścieków oczyszczonych, opartych na danych pochodzących z oczyszczalni ścieków komunalnych „Kujawy” w Krakowie oraz analizując rezultaty testów statystycznych, można stwierdzić satysfakcjonujący stopień zgodności wyników symulacji z wartościami rzeczywistymi w przypadku odpowiedniego zakresu parametrów jakości ścieków oraz częstotliwości ich pomiarów.

W oparciu o wstępne wyniki niniejszych badań można wnioskować, że w celu uzyskania wiarygodnych wyników symulacji pracy bioreaktora w modelu ASM niezbędne jest prowadzenie monitoringu podstawowych paramentów jakości ścieków w ilości około 200 serii pomiarowych.

\section{Literatura}

[1] Gupta H. V., Kling H., Yilmaz K.K., Martinez G.F.: Decomposition of the mean squared error and NSE performance criteria: Implications for improving hydrological modelling, J Hydrol, nr. 377, 2009, s. 80-91.

[2] Iacopozzi I., Innocenti V., Marsili-Libelli S., Giusti E.: A modified Activated Sludge Model No. 3 (ASM3) with two-step nitrification-denitrification, Environ Model Softw, nr. 22, 2007, s. 847-61.

[3] Keskitalo J.: Mechanistic modelling of pulp and paper mill wastewater treatment plants Jukka Keskitalo and Kauko Leiviskä, 2010.

[4] Moriasi D.N., Arnold J.G., Van Liew M.W., Binger R.L., Harmel R.D., Veith T.L.: Model evaluation guidelines for systematic quantification of accuracy in watershed simulations, Trans ASABE, nr. 50, 2007, s. 885-900.

[5] Mucha Z.: Operat wodnoprawny, MPWiK Kraków, 2014.

[6] Nelson M.I., Sidhu H.S.: Analysis of the activated sludge model (number 1), Appl Math Lett, nr 22, 2009, s. 629-35. 
[7] Pai T.Y., Ouyang C.F., Su J.L., Leu H.G.: Modelling the steady-state effluent characteristics of the TNCU process under different return mixed liquid, Appl Math Model, nr. 25, 2001, s. 1025-38.

[8] Petersen B., Gernaey K., Henze M., Vanrolleghem P.A.: Calibration of Activated Sludge Models: A Critical Review of Experimental Designs, In: AgathosSN, ReinekeW, eds. Biotechnology for the Environment: Wastewater Treatment and Modeling, Waste Gas Handling. Dordrecht, Springer Netherlands 2003. 101-86.

[9] Sochacki A., Płonka L., Miksch K.: Kilka refleksji o wykorzystaniu modeli matematycznych w symulacji procesów oczyszczania ścieków metodą osadu czynnego, Pol Inżynieria Środowiska pięć lat po wstąpieniu do Unii Eur, nr. T.1, 2009.

[10] Vandekerckhove A., Moerman W., Van Hulle S.W.H.: Full-scale modelling of a food industry wastewater treatment plant in view of process upgrade, Chem Eng J, nr. 135, 2008, s. 185-94.

[11] Zambrano-Bigiarini M.: hydroGOF: Goodness-of-fit functions for comparison of simulated and observed hydrological time series, 2014.

\section{COURSE OF WASTEWATER TREATMENT COMPUTER SIMULATION IN ACTIVATED SLUDGE REACTOR}

\section{S u m m a r y}

The aim of the research, the results of which are presented in this paper, was to determine the influence of the number and scope of raw sewage quality parameters on the reliability of the simulation results, that would allow to determine the optimal frequency of monitoring required to obtain data for ASM simulation programs. The article presents the methodology of computer simulation of the process of municipal wastewater treatment in bioreactors with activated sludge. The method of data preparation and processing of its input into the model as well as the methods of assessment and verification of simulation results by means of statistical tests are presented The modeling was done in the BioWIN software on the example of sewage treatment plant "Kujawy" in Krakow. On the basis of preliminary results of the study it can be concluded that in order to obtain the reliable results of bioreactor simulation in ASM model it is necessary to conduct the online monitoring of the main wastewater quality parameters.

Keywords: activated sludge method, wastewater monitoring, computer simulation, BioWin software

DOI: $10.7862 / \mathrm{rb} .2016 .163$

Przestano do redakcji: 01.05.2016 r.

Przyjęto do druku: 28.06.2016 r. 